\title{
Engaging Academics in Training in Information Communication Technology (ICT): An African Experience with special focus on Uganda
}

\author{
Abdullahi Hussein \\ Qatar Foundation \\ abdullahi.sheikh@gmail.com
}

\begin{abstract}
Training academics in ICT utilisation has been widely regarded as a key to successful staff development practice in higher education and, hence, considerable efforts and resources have been invested into ICT training programmes. However, little is known about the extent to which higher education policymakers in Africa give attention to the issue of preparing academics for ICT usage. This paper reports the findings of a research study exploring the utilisation of ICT in Uganda, Africa. Qualitative research methods were employed and data were collected through interviews, observations and open-ended questionnaires. The findings indicate that the university has put resources into the development of ICT policies, including policies related to training academics. Subsequently, academic staff were trained in ICT utilisation. However, little attention appears to have been given to the issue of engaging academics in ICT training. The paper also highlights the importance of engaging academics in ICT training for successful ICT staff-development outcomes.
\end{abstract}

\section{Introduction}

It has been suggested that the rapid development of information communication technology (ICT) has initiated unparalleled transformation in universities (Tagoe, 2012). This affects almost every country in the world. ICT in education represents a challenge and an opportunity for education in general, and for higher education in particular, since "open learning and distance education are at the forefront of educational responses to the changes that are taking place locally, regionally, nationally and internationally" (Uys, Nleya, \& Molelu, 2004, p. 69). Furthermore, the computer, which is the core piece of technology in this knowledge revolution, enters all aspects of people's daily lives and every discipline. Udo and Edoho (2000) have long argued that the potential benefits of ICT "cut across all sectors of economy and all fields of human activities" (p. 329). Thus, a great deal of ever growing literature continues to highlight the potential social and economic benefits that are associated with ICT (Akinsola, Herselman, \& Jacobs, 2005; Lelliott, Pendlebury, \& Enslin 2000; Stoica \& Vâlceanu, 2013; Williams, Pitchforth, \& O’Callaghan, 2010).

However, there are a number of limitations associated with ICT in education, including cultural effects and technological dependency (Amutabi \& Oketch, 2003; Woherem, 1993). Negative implications of ICT in Africa are widely reported in the literature (Cline-Cole \& Powell, 2004; Hall, 1999; Lai, 2012; Leye, 2009; Ya'u, 2004). These negative influences occur because computers reflect the views of their creators (Irwin, 2000; Sy, 2001). Thus, in relation to teaching in higher education, Lelliott, Pendlebury and Enslin 
(2000) argued that much of the content and style of the material produced in developed countries is not suitable for social and cultural traditions in developing countries.

In spite of the shortcomings of ICT in education, literature from developing, including African countries, continues to highlight the potential benefits that ICT in education could bring into higher education (Afifi, 2011; Ehlers, 2009; Grosseck, 2009; Kinuthia \& Dagada, 2008; Lwoga, 2012; Lubega, 2010; Mashhour \& Saleh, 2010). Preparing academics for ICT utilisation has further been noted as a prerequisite for successful ICT in higher education (Chitiba, 2011; Hoffman, 1996; Littejohn, 2002; McCarney, 2004; Roberts et al., 2002; White, 2007). Little is known of the extent to which African higher education focuses on the issue of training academics for ICT usages: this is the gap this paper attempts to fill in. The paper has two major objectives. Firstly, it was intended to provide a deeper understanding of the processes of incorporating ICT in an African context. Secondly, it was intended to investigate the extent to which African higher education institutions gave attention to the issue of preparing academics for ICT utilisation. The paper argues for the importance of engaging academics in the development and delivery of ICT staff development training and considers academics' engagements as a key to a successful ICT staff development policy.

\section{ICT in African Higher Education}

Flexible learning, access to education, lifelong learning, saving time and saving money are among the potential benefits that ICT can contribute to higher education (Afifi, 2011; Grosseck, 2009; Gunga \& Ricketts, 2006; Hanna \& Latchem, 2002; Mashhour \& Saleh, 2010; Uys, Nleya, \& Molelu, 2004). Due to these benefits, there is hardly a country in the world that is not actively engaged in the process of introducing ICT into its educational system (Tsitouridou \& Vryzas, 2004). Developed countries are continuing to discover different ways in which they can benefit, and developing nations are entering the competition of importing ideas and equipment from industrial nations. However, it has been widely reported that Sub-Saharan Africa, with the exception of South Africa, has not witnessed much development in terms of ICT in education at the university level and, in the process, faces a number of challenges in integrating ICT into higher education (Hassan \& El-Rify, 2012).

Higher education is a growing sector in Africa (Jowi, 2009; Sawyerr, 2004). Kenya, for instance, "had only one public university in 1986, and no private (Amutabi \& Oketch, 2003; Oketch, 2003). However, as of June 2013, the country has over thirty higher education institutions and twenty-two private higher institutions (Kenyan Commission for University Education, 2013). Ethiopian higher education has also witnessed expansion from two federal universities at the end of 1980s, to twenty-two universities in the last decade with the planned expansion of opening another ten (Ashcroft \& Rayner, 2012). Even Somalia, which has lacked a central government and an effective ministry of education since 1991, has witnessed a dramatic increase in its higher education from only two higher education institutions in 1991, to over fifty universities now (The Heritage Institute for Policy Studies, 2013; Leeson, 2006). This dramatic expansion that was witnessed by almost every African country has been termed as 'massification' (Ashcroft \& Rayner, 2012), and was argued to have led a 'quantityquality mismatch' in higher education (Owuor, 2012). 
Despite this expansion, access to higher education is still an issue that many countries in Africa are facing (Donat, 2001; Oketch, 2003). ICT in education has been suggested as a solution to the problem of access to higher education, which many African countries remind faced (Afifi, 2011; Donat, 2001; Simmons et al., 2011).

A relatively new and distance-based university called the African Virtual University (AVU) has started operating on the continent (Donat, 2001; Simmons et al., 2011). The AVU aims to bring high-quality education to a larger number of African students, thereby producing sufficient numbers of well-trained African scientists, technicians, engineers and business managers for economic development (Amutabi \& Oketch, 2003; Donat, 2001; Hanna \& Latchem, 2002; Simmons et al., 2011).

However, some researchers (Amutabi \& Oketch, 2003) argue that, in at least one country, there is no indication that the AVU is solving problems. The fees of the AVU in Kenya are reported to be more expensive than other universities (Amutabi \& Oketch, 2003). Moyo (2003) also reported similar concerns from AVU's locations in Zimbabwe. However, such issues are not unique to the AVU (Engelbrecht, 2005, p. 218):

Many ICT in education initiatives have failed to achieve the desired learning outcomes, because not enough attention has been given to good learning design, management of the ICT in education events, the selection of the right technology or to the adoption of ICT in education by instructors and learners.

This suggests that, not only the AVU, but many ICT in education initiatives are failing to fulfil their aims, as most African universities are still struggling to incorporate ICT into their teaching and learning (Macharia \& Nyakwende, 2010; Nsomwe-a-nfunkwa, 2010; Tagoe, 2012).

Several researchers have argued that the cause of the failure of ICT in higher education is not the poor ICT infrastructure, as the continent has "some of the most modern ICT facilities, that have been either donated or sold to its people, or have been assembled with the use of cheap labour" (Ocholla, 2003, p. 182). Britz et al. (2006) also made similar suggestions by arguing that Africa has made progress in terms of ICT development: "not only is there an exponential growth of ICTs on the African continent, but to a certain extent Africa has leapfrogged into new technology" (p. 32).

This suggests that Africa has developed technologically beyond the expectations of many. As Ojo (2005) argued, "having technologies is one thing, but whether or not people can use them effectively is another thing entirely" (p. 95). Moreover, this is what seems to be happening on the continent. The availability of "modern" technology did not automatically make the higher education institutions on the continent use the technology.

Obstacles that African higher education institutions are facing are not due to poor ICT infrastructure, but rather to the readiness of the continent for ICT changes (Ilfinedo, 2005). Readiness for ICT development must start by considering how well prepared the staff in 
higher education is for these changes before considering any ICT programme that might be implemented.

\section{Preparing Academics for ICT Utilisation}

The issue of staff readiness to use ICT cannot be underestimated. The intention to adopt ICT in higher education is not an aim in itself, but rather a means to achieve pedagogical and instructional objectives. ICT should not be acquired because it has a special status and is different from traditional approaches, but rather because of its usefulness to the teaching and learning processes. Thus, Oliver and Dempster (2003) argued that the process of integrating an ICT curriculum should be pedagogically led rather than technology driven. Changing practice by academic staff has been considered vital for the successful implementation of ICT projects in higher education. However, such changes do not automatically follow from a flow of information or just by providing the latest technological development (ibid). Stensaker et al. (2007, p. 431) highlighted the importance of linking effectively between "purpose, people and pedagogy" for the success of ICT in higher education.

Training academics to use ICT has generally been accepted as a critical step towards successful ICT development in higher education (Hussein, 2012). Some countries, such as the UK, have gone a long way towards producing different approaches to supporting academics in this way, and many universities have given considerable attention to this matter (Clegg et al., 2000; Littlejohn, 2002; Littlejohn \& Campbell, 2003; Oliver \& Dempster, 2003; McCarney, 2004; Quinn, 2003).

In Africa, newly emerging literature appears to be highlighting the importance of ICT staff development as an important step for ICT implementation (Afifi, 2011; Lwoga, 2012). However, there is no evidence to suggest that African higher education institutions, excluding South Africa, have given as much consideration to staff development as they did to ICT facilities. As Lelliott et al. (2000) noted, "little attention seems to have been given to the question of how best to prepare teachers in Africa for the educationally sound use of ICT" (p. 50). There are strong forces at play that want to create computer facilities, but who are less interested in the support of human resources being made available. Furthermore, Quinn (2003) argued that university teachers in Africa have undergone little or no training for their role as lecturers, let alone trained for ICT usage. To complicate the matter further, it is probable that higher education institutions in Africa are using imported ICT staff development approaches, which would mean that Africa is not only importing ICT facilities, but also ways of training their own people.

\section{Methodology}

The study used qualitative research methods. These methods were the most appropriate for this study because the researcher did not want to predetermine the participants' answers, but rather wanted to explore and make sense of how participants viewed the matters that were under investigation. Importantly, qualitative research approaches allow the situation to be investigated within its natural contexts and the 
experiences of individuals' participants to be documented (Creswell, 2003). These were the two major reasons that led to the adoption of qualitative research methods. Interviews, observations, document analysis and field note techniques were all used in this study. All the interviews were digitally recorded and transcribed. Before any interview was carried out, participants' right of withdrawal from the interview at any stage and other ethical issues were discussed. All participants signed a consent form on which they stated their willingness to participate in this research. Data were collected in months of February and March of 2006 at a public university in Uganda. Participants in the research included six academics, four academic developers, an ICT in education administrator and a senior staff member at the university level. Furthermore, 15 academics responded to the open-ended questionnaires that were administered. The participants in this study were selected based on their involvement in the ICT in education academic development. Academics' participation in the training was the main criterion used to decide whether they should participate in this study or otherwise. The selection of academic developers was also based on their training experience. Any academic developer who had not administered training was not involved in the study. The senior staff member, who was the dean of the faculty where the participating academics were based, hosted the research. He was also a member of the university's senate, which decides, amongst other things, the university's direction toward ICT in education development.

Rich data were collected for this study; however, due to the impracticality of presenting all the data in this article, only the major findings from five representative participants will be presented. Results from the senior academic, two academics and two academic developers are presented here. These particular participants were selected because their data were typical of the participants in their respective groups. However, this was obviously not possible in the case of the senior academic, who was the only senior academic taking part in the study.

After data had been collected, interviews were transcribed and then read, and, based on this reading, certain repeated (or similar) phrases from across the transcripts were gathered together. Where phrases related to more than one idea, a judgment was made about the main concern of the excerpt, and this was classified into one category. Each category was then reviewed to see the range of ways in which this topic had been discussed.

Finally, quotations were used to illustrate each theme. The choice of quotations as an illustration of these themes was based on one of the following two criteria: because it was the best description of an issue or because it was typical. If a number of individuals expressed a particular view or best described a situation, then it was used.

\section{Results and Discussions}

\section{ICT Staff Development Policy}

The findings of this study reveal that the university had an ICT policy that can be found in two comprehensive policy documents. The ICT policies had been developed over the last few years. The implementation of the first policy document began in 2000 and was 
meant for a four-year period, while the second ICT policy was meant to cover another four years, which started when the first master plan ended.

When you start looking at the different documents we have, you realise that there was a master plan...it sets out actually (a) plan how ICT was going to be introduced to the university. Both office automation services like buying computers and training people, how to use office supplies and stuff like that, setting up infrastructure and eventually introducing value added services including ICT in education, information systems like student records, library catalogues, and all those kind of things (Senior Academic).

The university's gradual process of implementing ICT was one of the interesting things that this participant suggested. This process started with setting up an ICT infrastructure and ended with training people on how to use technology for pedagogical purposes. This clearly suggests that issues such as training academics to use ICT for pedagogical purposes came at a later stage. Nevertheless, the policy documents have explicitly highlighted the importance of preparing academics for ICT utilisation and not only provided details of how academics who are already in the university should be training, but also clearly set out the possession of basic ICT skills as a requirement for new recruits who want to join the university.

Before appointment to Assistant Lecturer, academic staff are required to demonstrate the prescribed level of competence in technology enhanced interactive learning techniques (The Policy Documents).

Even though the focus here seems to be on new recruits, different parts of the document set deadlines for existing academics to reach the 'prescribed' level of ICT competency. The documents have additionally highlighted the importance of providing continuous training for academics in order for them to update their knowledge and skills in the field of ICT.

Another important development that the policy documents have highlighted is the establishment of a central unit that will be in charge of overall ICT support for the whole university, with particular emphasis on technical aspects.

One centrally organised, service-oriented, unit (not necessarily geographically concentrated) will be formed. This unit will be formalised immediately. The primary tasks of this unit/department are management and maintenance of common ICT systems and end-user support...all necessary functions/skills for day-to-day management of all ICT resources and user support services will be gradually developed during the four years starting 1 January 2001 (The Policy Documents).

Thus, the centre was established in 2001 - just a year after the first master plan came into effect. The initial aim for this centre was to provide technical help such as a network and infrastructure for the whole university whenever it is required. 
Having an ICT policy at an institutional level has been recognised as an important step towards developing ICT projects. Jenkins et al. (2001), Smith (2002) and Stiles (2003) all identified the lack of institutional learning technology strategies as an obstacle to ICT development in higher education. As a result, Stiles and Yorke (2004) reported that the universities, especially in the UK context, have moved away from this lack of strategy as "many, if not most, institutions have either learning and teaching strategies which include ICT in education, or direct ICT in education strategies" (p. 2). This clearly highlights that the findings, which discussed the importance of ICT policies reported here, seem to support a growing view in the literature in the field. Importantly, establishing a centre dedicated to supporting academics has been identified as an important step towards ICT development in the higher education context (Weaver, 2006).

\section{Delivering Training to Academics}

On the practical aspect, the policy documents equally gave considerable attention to the subject of training academics for ICT utilisation and preferred virtual learning environment (VLE) tools. Blackboard, ETUDE (the university has never used this program), KEWL (Knowledge Environment for Web-based Learning: The Next Generation) and WebCT were among the packages that the policy documents have recommended for training use as well as for virtual learning packages. However, Blackboard and KEWL were the only tools used in the training. The university's policies clearly favoured KEWL over Blackboard, partly because Blackboard was costing the university a considerable amount of money in the form of a licensing fee, while KEWL was free of charge.

In an effort that can be seen as a gradual implementation of ICT staff development, the university policymakers have identified five faculties and named them as "priority faculties". Academics from these faculties were given training on using ICT for pedagogical purposes. All academics that the researcher talked to, or who responded to the open-ended questionnaires, said they had taken part in at least one training cycle. However, none had attended more than two training cycles, which should not be too surprising given the fact that the training scheme was only introduced recently. Training cycles varied from three days to an entire week and covered a wide range of issues.

The fact that training varies from three days to a week does not suggest that the ICT support unit had taken into account academics' different levels and ICT needs and, therefore, based their training on that information. This was not the case, as academics had little involvement in the planning of the training. The reason why training had different lengths of timing was mainly due to circumstances such as the availability of the trainers and number of academics who were available for training.

Training was mainly carried out during semester breaks, and academics had mixed views on whether the timing of the training was appropriate. Some academics believed that the holiday period was an ideal time for training as academics would not be busy teaching their students. Other academics, on the other hand, disagreed about the holiday being a 
suitable time for training, as they viewed the holiday period as a time they should be spending with their families.

Additionally, since training was delivered in an intensive block of three days to a week, academics expressed their wishes for the training to be spread over the whole semester. A senior academic at the university agreed with the logic of spreading the training over the semester, but highlighted the difficulties of doing so:

Yeah, that one we have it in plan and we are going to do it that way. But, for the beginning when we are getting experts, you cannot get an expert from the UK to come and be here for one semester, you get it, and you cannot give this person four tickets or so. So, the experts come for a shorter period, so up to when the experts have trained some of the local staff and given them several refresher courses (Senior Academic).

At the training sessions, academics were first introduced to general teaching principles: how to prepare a lesson and deliver and present brief discussions on educational psychology. This brief discussion about teaching methods was particularly well received among academics who had backgrounds other than education and had never had similar opportunities before. KEWL was then explored in a very detailed manner. Topics such as how to upload materials on the Web, how to communicate with students and how to make an online assessment using this tool were some of the areas covered.

To upload our files there to provide functionality for students to communicate with lecturers, that is through email and through other things like uploading files by students make the assessments (Female Academic).

A female participant added, "you can play around with all those tools," referring to the different functionalities such as email and discussion boards that the KEWL tool had.

One academic provided a detailed account of what she was taught in the training:

They taught us how to design courses, and how to interact with the students, chatting through the chat rooms, students can query your notes if they don't understand, how to design quizzes for them, how they can take the quizzes, so a teacher can always access the students even not physically in class, but in chat rooms, they can always, umm, get any help through the chat rooms. So the tutors, basically they covered everything that we needed for... for our courses (Female Academic).

Training academics for ICT usage is such an important issue that, as Littlejohn (2002, p. 166) noted, "many academics have limited experience in ICT for teaching and learning and lack familiarity with current thinking in educational technology". Thus, academics' lack of understanding of how technology is used pedagogically is likely to have an impact on students' learning. In addition, it appears as though the university has acknowledged the significance of this matter. Supporting academics for ICT utilisation as reported here does appear to have wide support in the literature (Roberts et al., 2002; Littejohn, 2002:, 2003). 


\section{Changing Academics' Practices}

To examine whether academics had changed their practices and applied the skills they gained from the training, we examined the extent to which academics have uploaded learning materials on KEWL. This does not necessarily mean that this criterion was the most appropriate in such situations, but since academic developers considered uploading learning materials as one of the most important things that academics should be doing after the training, it was reasonable to use the academic developers' own criteria to judge the extent to which they had realised their set target. More importantly, after attending training, academics were expected to register themselves in KEWL and start uploading learning materials. This was arguably, as mentioned above, the most important role that academics were expected to perform after training. Additionally, since KEWL was newly developed software, lecturers were also expected to provide feedback about the tool after uploading learning. It is unlikely, however, that an academic would provide feedback if they have never tried to use the tool.

All the academics that responded to the questionnaires have enthusiastically discussed the skills they gained from these training workshops and what they got out of the training sessions they attended. These were meant to improve lecturers' communication skills with their students and make them more effective communicators. It seems as though academics have gained useful skills from the training they attended, but the question here is whether they ever used these skills for their teaching. A male lecturer, for instance, pointed out that he has not used the skills he has acquired without giving any reason for this:

I have not; I haven't used much ICT in education in my teaching this semester. I haven't used much, because I've told you I haven't even uploaded the notes on the ICT in education software. So I haven't used it much (Male Academic).

Even though this academic was not using the skills he gained from training, he was, however, using different skills or perhaps his 'own' way of doing things rather than the approach in which he had been trained.

I communicate with my students through, ah, through, ah... groups like these, ah, mail groups, like on Yahoo groups, like that. So we communicate in that way, everybody joins the groups...when I send a message on notes...I use the group's acc...eh, the mail groups than uploading them in the software...they didn't teach me that (using Yahoo group). That one I taught myself (Male Academic).

Despite attending training and presumably gaining 'useful' skills, this academic has not changed his way of doing things. He did not intend to apply the skills he gained from the training any time soon: he seemed to be, along with his students, "comfortable" communicating through Yahoo groups. This was a clear indication that academics were not necessarily against technology as such, even if they chose not to use this kind of technology.

It is not, however, only this academic who had been using different skills other than what he had been trained in: other academics did not use the skills either. A female staff member, for instance, pointed out that she was not using the skills she had gained from the 
training, but instead was "using other skills". Another female staff academic has similarly confirmed that she has not applied the skills gained at all, as the course she taught that semester was already online and did not require her to create any new materials.

Because the course I teach is online...it's Cisco and Cisco is online so the curriculum of Cisco is online already on another Cisco website, so I do not now need to go to NextGen except if I find information that is not offered in the Cisco curriculum that students need and is in another curriculum. But, I have not found one as yet. But, I hope I can in future use it (Female Academic).

Other academics have also admitted that they had not used the skills as the courses they taught were already online and there was not much need for them to put learning materials online. This raises the question of whether ICT academic developers considered academics' training needs as criteria when planning for training.

Uploading learning materials on the web was an important task that academics were expected to perform. However, it seems that the reasons for uploading content on the Internet have not been explained adequately to the academics. As pointed out earlier, academics preferred to use different technology when communicating with their students and have yet to apply these new skills. Thus, if the reason why academics were taught how to upload learning materials was to equip them with new skills that they would use when communicating with their students and enable the students to access learning materials, then this has, without doubt, not been successful. Academics continued communicating with their students in the same ways they had before they took part in the training. This obviously raises the question of whether there was a need for training in the first place. This is, however, not to question the need for academics to be trained for ICT usage. On the contrary, the need for training was obvious and academics constantly argued the importance of having such training, but it appeared that the current training regime for the university was, to some extent, very narrow. Equipping academics with the skill of how to upload materials seemed to be considered the most important thing for academics to master.

\section{The Underlying Reasons}

As pointed out, academics had not put the training they attended into practice. Different issues were suggested to be the contributing factors that led academics to be reluctant to apply those skills. Some academics, for instance, pointed out the lack of a reward scheme as a main reason for this.

Lack of motivation...as like, if someone knows that much as I go there to train, I'm not going to be paid for that...for my allowances, maybe like I would spend like two weeks there seated (Male Academic).

What this academic seems to suggest is that financial rewards for academics for the period they are away for the training would motivate them, which will eventually lead to uploading materials on KEWL. The financial incentive that this participant is referring to has its basis in the literature in the field. For instance, Weaver (2006, p.281) reported that, in order to 
encourage academic staff to take part in the training, Monash University introduced "a program of Unit Innovation Grants, where staff could apply for small grants to assist them integrate online learning in their campus-based programs". The findings of this research, however, revealed that the faculty where this study took place provided substantial financial rewards for any academic who put their study materials online. Apparently, this did not seem to work either: "so the carrot did not work, the stick did," said a trainer, referring to the ineffectiveness of the reward policy and the effectiveness of the 'harsh' policy that the university followed, which will be examined at a later stage.

Academics have, on the other hand, blamed management's lack of a 'strong' position towards academics who fail to apply the skills as a reason for the lack of implementations.

Failure by the management to apply [the] rule...if a rule was set, then it would be, I think then people would go on and follow the rule (Male Academic).

He further suggested that management should consider using strong positions against academics who are not taking part in the training and eventually applying the skills they gained. This was precisely what the university management had been doing, as will be explained further in the next section. This was an ineffective policy too. Repeatedly, the importance of attending training or else losing their jobs was reiterated to the academics. However, that 'strong' policy did not go beyond making academics attend training and was not effective at all when it came to applying the skills.

Academics' lack of implementation of the skills gained from training was 'an open secret' that even staff developers were aware of and had their explanations. Staff developers believed that about 70 per cent of people they trained had not used the skills and did not put any courses online.

A total of 90 people, I would say, have been training now - as of now - within the priority faculties. I would say about 30 have started somehow on course development, umm, about seven to eight courses are complete (Male Staff Developer).

A staff developer attributed this to two main reasons. First was the lack of 'institutionalised use of e-content' at the university level, which resulted in lecturers perceiving putting materials online to be an extra load. The second reason that staff developers gave for the lack of interest among academics was 'lack of access'; in other words, lack of computer facilities. However, these two reasons that the staff developer gave cannot go unchallenged. The lack of 'institutionalised use of e-content' is a rather weak justification. As pointed out, the university has had clear ICT policies that have constantly been reviewed and has set up a department that was in charge of ICT support and management-related issues. Some academics might always be difficult to persuade to change, but to find the overwhelming majority of academics reluctant to apply skills cannot be blamed on 'fear' of workload.

At a practical level, 'reasonable' ICT infrastructure was in place and, at least in the priority faculties, adequate for academic to use. The researcher observed that the university, 
especially at the faculty visited, had no problems with availability of or access to personal computers: the faculty has computer labs that academics could use. This does not suggest that computers were 'sufficient' for all academics, but it rather means that there was no shortage of access to cause academics' lack of implementation of the training.

Computers were not only available at the faculty where the researcher was based: other faculties also had ICT in education computer labs that were set up by the ICT support department. As another staff developer pointed out, "within each priority faculty we have set up a lab: a computer lab specifically for ICT in education, with 50 PCs each." This suggests that problems with accessing computers were not a major reason for not applying the skills. If we closely examine the above two reasons given by the staff developer for academics' lack of use of the skills gained, it seems that the staff developer was laying the blame on either university decision-makers or the academics themselves. However, there was no suggestion that they should take part of the blame, even though they were the department that was in charge of ICT within the university. They never, for example, questioned whether their policies towards academics might be the reasons for academics not using the skills.

The result of this study suggests that academics were not engaged in the training and had little choice not to attend the training. This means that neither academics' needs for training nor their appropriate time for training were discussed with them before training was delivered to them. In fact, academics were not involved in any consultation process about the content of the training that had been offered.

We were just asked to go for training; they did not like say, 'can staff say what they want'. But, I think what they thought we wanted was to learn so many things...all we wait for is there...an e-leaning session and if we are called we attend (Female Academic).

This demonstrates that academic developers delivered training that did not give regard to whether academics needed the skills or not. Academics pointed out that they had not attempted to influence the content of training that academic developers arranged for them. "This is because I wasn't asked to contribute to the workshop content by organisers," pointed out a male academic.

Other academics also argued that the content of the training was already set and there was no room for them to contribute: “.... at the training you find prearranged programmes (and instructors) which you cannot change to suit your needs" (Male Participant). Such views were commonly expressed by academics who attended the training. Equally, these views were also found among academics who did not even attend the training.

Academics wanted to be consulted and involved with the planning. "Consulting people is good because they can plan for that thing", argued a female staff member. Further, some academics have highlighted the importance of consulting them before developers decide to train them so that academics could be given the training they require. "We need to actually be given the software we need, which is why I said it is also better if they first 
contact us [and ask us questions such us] 'what kind of software would we need?" (Male Academic).

Other academics have explicitly attributed their failure to apply skills to their lack of involvement in the planning of the training programmes.

I feel that they would have come with something like questionnaires. What would you expect in an online course? How would you want to view an online course and how would you want an online course? What should it have and what shouldn't it have? And, how, of course, basing on the knowledge of other ICT in education courses, how you would want it to be different from them or better or similar in some way. If they had given us such a provision, then maybe they could have used those tools that are familiar with some students and some of the lecturers (Female academic).

In addition to the lack of involvement of the academics in the training, it appears that the university has also adopted the policy of 'forcing' academics to take part in the training: any academic who failed to take part in the training risked losing their job.

We moved and came up with a policy that if you don't take this training you won't be promoted, or if you are at the lower rank you can actually be dismissed at some point. So, members of staff came because of that, but in the process they appreciated it and they now think it is the best thing for them (Senior Academic).

The university took such a strong stand about forcing academics to take part in the training because, they argued, they did not want students to 'suffer' as a consequence of academics' reluctance to take part in the training being offered.

If you're going to be so soft with them they are not going to acquire those skills as soon as possible. The students will suffer in the long term. So, we're doing it because we want them to acquire the skills now and teach the current students (Senior Academic).

What is worth mentioning is that this strong policy had not been used with senior staff members; it was mainly applied to junior staff. According to him, this was because higherranking academics would soon leave the university due to retirement or other reasons, while junior or younger academics were likely to stay at the university for years to come.

We're saying this is compulsory for all staff at this level but it is optional for the other group [senior]. And you find that actually $75 \%$ of them [senior] came and attended. But, if I state it's compulsory then you may find that even the percentage has been lowered: they're simply not coming, you know? So, but say to them 'this is good for all junior staff, we think it is also good for you. But, for you it's not compulsory, please come and attend' (Senior Staff Member).

Even though the ICT in education training that the university offered to academics was compulsory for junior staff members, the academics who took part in this study made it 
clear that, if it were voluntary, they would still have attended because they valued the training. "If I was given an option of coming or not, I think I would go there." This suggests that the forcing of academics to train was based on prejudice, not the evidence of staff attitudes.

Forcing academics to take part in training has been considered counterproductive, and instead, a voluntary-based training formula was found to be more effective. Weaver (2006, p.284) argued that "forcing staff to incorporate online teaching when not appropriate or when staff do not feel ready for such a change was considered counterproductive." Vogel (2010) has also highlighted the importance of engaging academics in their professional development for technology-enhanced learning. Jenkins et al. (2001) too have confirmed the importance of engaging academics and addressing their common cry.

\section{Conclusions and Recommendations}

This paper has drawn upon the results of a wide study that took place in a public university in Uganda, Africa. This case study revealed that African higher education institutions have given due consideration to its ICT staff development; this has been largely missing from the available literature in the field. However, in this paper, we have shown that the university adopted a policy of 'forcing' academics to take part in the training, and little attention was given to their training needs. Academics wanted to be consulted and involved with the planning and implementation of the training, but no attempts were made by senior managers or ICT staff developers to engage them beyond requiring academics to attend training. This approach was found to be ineffective; academics had failed to use the skills and knowledge they gained from training in their practice.

In light of these research findings, the study calls for the active engagement of academics as a critical factor for successful ICT staff development in Africa. It recommends that ICT staff developers and senior administrators consult with academics; that they seek their views, for example, on the content and relevancy of the training that is being offered to academics. 


\section{References}

Akinsola, O., Herselman, M., \& Jacob. (2005). ICT provision to disadvantaged urban communities: A study in South Africa and Nigeria. International Journal of Education and Development Using Information and Communication Technology, 1(3), 19-41.

Afifi, G. M. H. (2011). E-learning as an alternative strategy for tourism higher education in Egypt. Quality Assurance in Education, 19(4), 357-374

Amutabi, M. N., \& Oketch, M. O. (2003). Experimenting in distance education: The African Virtual University (AVU) and the paradox of the World Bank in Kenya. International Journal of Educational Development, 23(1), 57-73.

Ashcroft, K., \& Rayner, A. (2012). The purposes and practices of quality assurance in Ethiopian higher education: Journey, adaptation and integration. International Journal of Business Anthropology, 3(2), 19-35.

Britz, J. J., Lor, P. J., Coetzee, I. E. M., \& Bester, B. C. (2006). Africa as a knowledge society: A reality check. The International Information \& Library Review, 38, 25-40.

Chitiba, C. A. (2011). E-learning - A potential answer for higher education's challenges. Euromentor Journal, 2.4 (December), 1-7.

Clegg, S., Konrad, J., \& Tan, J. (2000). Preparing academic staff to use ICTs in support of student learning. International Journal for Academic Development, (2), 138-148.

Creswell, J. W. (2003). Research design: Qualitative, quantitative, and mixed methods approaches. London, England: SAGA Publications.

Donat, B. N. P. (2001). International initiatives of the virtual university and other forms of distance learning: The case of the African virtual university. Higher Education in Europe, 26(4), 577-588.

Ehlers, U. D. (2009). Web 2.0- e-learning 2.-0-quality 2.0? Quality for new learning culture. Quality Assurance in Education, 17(3), 296-314.

Engelbrecht, E. (2005). Adapting to changing expectations: Post-graduate students' experience of an e-learning tax program. Computers and Education, 45(2), 217-229.

Gunga, S. O., \& Ricketts, I. W. (2006). Facing the challenges of e-learning initiatives in African universities. British Journal of Educational Technology, 38(5), 896-906.

Grosseck, G. (2009). The use or not use web 2.0 in higher education. Procedia: Social and Behavioral, 1(1), 478-478.

Hall, M. (1999). Virtual colonisation. Journal of Material Culture, 4(93), 39-55.

Hanna, D, E., \& Latchem, C. (2002). Beyond national borders: Transforming higher education institutions. Journal of Studies in International Education, 6(2), 115-133.

Hassan, W., \& El-Rify, G. Hussein. (2012, June 21-22). E-learning in Egypt - Challenges and imperatives: Considerations of (design education) e-learning courses in Egypt. Paper presented at International Conference on E-learning, Hong Kong, China. Kidmore End: Academic Conferences International Limited.

The Heritage Institute for Policy Studies (HIPS). (2013). The state of higher education in Somalia: Privatization, rapid growth, and the need for regulation. http://www.heritageinstitute.org/wpcontent/uploads/2013/08/HIPS_Higher_Education_ENGLISH.pdf [Accessed 3rd November 2013].

Hoffman, B. (1996). What drives successful technology planning? Journal of Information Technology for Teacher Education, 5(1), 43-55.

Hussein, A. (2012). Freirian and postcolonial perspectives on e-learning development: A case study of staff development in an African university. International Journal of Critical Pedagogy, 4(1), 135-153. 
Ilfinedo, P. (2005). Measuring Africa's e-readiness in the global networked economy: A nine-country data analysis. International Journal of Education and Development, 1(1), 53-71.

Irwin, L. (2000). Gender inequalities in technology in developing nations: Females and computers in traditional cultures. Intercultural Education, 11(2), 195-200.

Jenkins, M., Armitage, S., \& Browne, T. (2001). Management and implementation of VLEs in UK universities: A UCISA funded survey. UCISA. Retrieved from: http://www.ucisa.ac.uk/groups/tlig/vle/VLEsurvey.pdf [Accessed 3rd April 2012].

John, M. (1996). Distance education in Sub-Saharan Africa: The promise vs the struggle part 1. Open Learning Journal, 11(2), 3-12.

Jowi, J. O. (2009). Internationalization of higher education in Africa: Developments, emerging trends, issues and policy implications. Higher Education Policy, 22, 263-281.

Kenyan Commission for University Education (2013). http://www.cue.or.ke/services/accreditation/status-of-universities [Accessed 15th December 2014].

Kinuthia, W., \& Dagada, R. (2008). E-learning incorporation: An exploratory study of three South African higher education institutions. International Journal on E-Learning, 7(4), 623-639.

Lai, L. (2012). Culturally responsive art education in a global era. Art Education, 65(5) 1823.

Leeson, P. (2006). Better off stateless: Somalia before and after government collapse. The Austrian Economists. Retrieved from: http://www.peterleeson.com/Better_Off_Stateless.pdf [Accessed 12th December 2013].

Lelliott, A., Pendlebury. S., \& Enslin, P. (2000). Promises of access and inclusion: Online education in Africa. Journal of Philosophy of Education, 34(1), 41-52.

Leye, V. (2009). Information communication technologies for development: A critical perspective. Global Governance, 15, 29-35.

Littlejohn, A. H. (2002). Improving continuing professional development in the use of ICT. Journal of Computer Assisted Learning, 18(92), 166-174.

Littlejohn, A., \& Campbell, L, M. (2003). From pilot project to strategic development: Scaling up staff support in the use of ICT for teaching and learning. Journal of Further and Higher Education, 27(1), 47-52.

Lwoga, E. (2012). Making learning and We 2.0 technologies work for higher learning institutions in Africa. Campus Wide Information Systems, 29(2), 90-107.

Lubega, J. (2010). Using ICT to enhance knowledge management in higher education: A conceptual framework and research agenda. International Journal of Education and Development Using Information Communication Technology (IJEDICT), 6(4), 83-101.

Macharia, J., \& Nyakwende, E. (2010). Influence of university factors on the students' acceptance of internet based learning tools in higher education. Journal of Communication and Computer, 7(10), 72-82.

Mashhour, A., \& Saleh, Z. (2010). Evaluating e-learning in Jordanian institutions: Why is it lagging? Quarterly Review of Distance Education, 11(4), 269-279.

McCarney, J. (2004). Effective models of staff development in ICT. European Journal of Teacher Education, 27(1), 61-72.

McNaught, C. (2003). The effectiveness of an institution-wide mentoring program for improving online teaching and learning. Journal of Computing in Higher Education, 15(1), 27-45.

Moyo, S. (2003). Distance learning and virtual education for higher education in Africa: Evaluation of options and strategies. African and Asian Studies, 2(4), 987-521. 
Nsomwe-a-nfunkwa, B. (2010). Challenges in higher education distance learning in the Democratic Republic of Congo. Distance Learning, 7(3), 31-33.

Ocholla, D. N. (2003). An overview of information and communication technologies (ICT) in the LIS schools of Eastern and Southern Africa. Education for Information, 21(2-3), 181-194.

Ojo, T. (2005). Wiring Sub-Saharan Africa for development. International Journal of Education and Development using Information and Communication Technology (IJEDICT), 1(3), 94-107.

Oketch, M. (2003). The growth of private university education in Kenya: The promise and challenge. Peabody Journal of Education, 78(2), 18-40.

Oliver, M., \& Dempster, A. J. (2003). Embedding ICT in education practices. In: R. Blackwell \& P. Blackmore (Eds.), Towards strategic staff development in higher education (pp. 142-153). SRHE/OU Press, Berkshire, England, UK.

Owuor, N. A. (2012). Higher education in Kenya: The raising tension between quantity and quality in the Post-Massfification Period. Higher Education Studies, 2(4), 126-136.

Quinn, L. (2003). A theoretical framework for professional development in a South African university. International Journal for Academic Development, 8(1/2), 61-75.

Roberts, J., Brindley, J., Mugridge, I., \& Howard, J. (2002). Faculty and staff development in higher education: The key to using ICT appropriately? The Observatory on Borderless Higher Education. Retrieved from: www.obhe.ac.uk [Accessed 14th February 2012].

Sawyerr, A. (2004). Challenges facing African universities: Selected issues. African Studies Review, 47(1), 1-59.

Simmons, L., Mbarika, I., Mbarika, V. W., Thomas, C. A., Tsuma, C., Wade, T. A., \& Wilkerson, D. (2011). TeleEducation initiatives for Sub-Saharan Africa: The case of the African virtual university in Kenya. Journal of STEM Education: Innovations and Research, 12(5), 78-90.

Smith, T. (2002). Strategic factors affecting the uptake, in higher education, of new and emerging technologies for learning and teaching. York: Technologies Centre. Retrieved from: www.techlearn.ac.uk/NewDocs/HEDriversFinal.rtf [Accessed 11th April 2012].

Stensaker, B., Maassen, P., Borgan, M., Oftembro, M., \& Karseth, B. (2007). Use, update and integration of ICT in higher education: Linking purpose, people and pedagogy. Higher Education, 54(3), 417-433.

Sy, P. (2001). Barangays of IT: Filipinizing mediated communication and digital power. New Media \& Society Journal, 3(3), 296-312.

Stoica, I., \& Vâlceanu, G. L. (Eds.) (2013). The impact of e-learning platforms in higher education. The $9^{\text {th }}$ International Scientific Conference eLearning and software for Education, Bucharest, April 25-26. Universitatii Nationale de, Editura.

Stiles, M. J. (2003). Embedding e-learning in a higher education institution. Keynote Paper for: At the Interface - 2nd Global Conference on Virtual Learning and Higher Education, 12th -13th September 2003, Mansfield College, Oxford. Pre-print available at http://www.staffs.ac.uk/COSE/cosenew/ati2stilesrev.pdf [Accessed 3rd April 2012].

Stiles, M. J., \& Yorke, J. M. E. (2004). Embedding staff development in e-learning in the production process and using policy to reinforce its effectiveness. Paper presented at the 9th SEDA Conference, Birmingham, UK. Retrieved from http://www.staffs.ac.uk/COSE/cosenew/embedding.pdf [Accessed 10 $0^{\text {th }}$ July 2014].

Tagoe, M. (2012). Students' perceptions on incorporating e-learning into teaching and learning at the University of Ghana. International Journal of Education and 
Development Using Information and Communication Technology (IJEDICT), 2012, 8(3), 91-103.

Tsitouridou, M., \& Vryza, K. (2004). The prospect of integrating ICT into the education of young children: The views of Greek early childhood teachers. European Journal of Teacher Education, 27(1), 29-45.

Udo, G., \& Edoho. F. (2000). Information technology transfer to African Nations: An economic development mandate. Technology Transfer Journal, 25(3), 329-342.

Uys, P. M., Nleya, P., \& Molelu, G. B. (2004). Technological innovation and management strategies for higher education in Africa: Harmonizing reality and idealism. Education Media International, 41(1), 67-80.

Vogel, M. (2010). Engaging academics in professional development for technologyenhanced learning. Goldsmiths: University of London. Retrieved from http://www.gold.ac.uk/media/Engaging\%20Academics.pdf [Accessed 10 ${ }^{\text {th }}$ August 2013].

Weaver, D. (2006). The challenges facing staff development in promoting quality online teaching. International Journal on E-Learning, 5(2), 275-286.

White, S. (2007). Critical success factors for e-learning and institutional change - Some organisational perspectives on campus-wide e-learning. British Journal of Educational Technology, 38(5), 840-850.

Williams, C. D., Pitchforth, E. L., \& O'Callaghan, C. (2010). Computer, the Internet and medical education in Africa. Medical Education, 44(5), 485-488.

Woherem, E. (1993). Informational technology in Africa: Challenges and opportunities. Kenya: ACTS Press.

Ya'u, Y. Z. (2004). The new imperialism \& Africa in the global electronic village. Review of African political economy 31(99), 11-29. 